\title{
MANAJEMEN PRAKTIS USAHA MIKRO BERBASIS AGROINDUSTRI SEBAGAI UPAYA MENUMBUHKAN JIWA KEWIRAUSAHAAN PETANI SEBAGAI PELAKU AGRIBISNIS DI DESA PALASARI DAN DESA CISAAT KEC. CIATER KAB. SUBANG
}

\section{PRACTICAL MANAGEMENT OF AGROINDUSTRY-BASED MICRO BUSINESS AS MEASURES TO GROW FARMERS' ENTREPRENEURIAL SPIRIT AS AGRIBUSINESS ACTORS AT PALASARI AND CISAAT VILLAGES, DISTRICT OF CIATER, SUBANG}

\author{
${ }^{1}$ Pandi Pardian, ${ }^{2}$ Hesty Nurul Utami dan ${ }^{3}$ Agriani Hermita Sadeli \\ ${ }^{1,2,3}$ Departemen Sosial Ekonomi Pertanian, Fakultas Pertanian, Universitas Padjadjaran Jalan Raya \\ Bandung Sumedang KM 21, Jatinangor, Sumedang - 45363 \\ e-mail: ${ }^{1}$ pandi.pardian@unpad.ac.id, ${ }^{2} h e s t y . n u r u l @ u n p a d . a c . i d,{ }^{3}$ agriani.hermita@gmail.com
}

\begin{abstract}
Subang Regency is one of the production centre of several superior agribusiness commodity in West Java, but the level of utilization of a portion of the agribusiness production as raw materials for agro-industries through independent entrepreneurial activities of the farming community that still less becoming the factors of the implementation of these community service activities. Micro and small businesses has been proven to make a significant contribution to the national economy in Indonesia. Based on this, it becomes an important to conduct the training /coaching to the farmers as one of the agribusiness doer in improving knowledge, skills regarding the practical management of micro enterprises based agro-industry in an effort to foster entrepreneurial, to contribute significantly to the improvement of economic income families. This activity is carried out with the aim of fostering the entrepreneurial spirit, practical management knowledge, and the knowledge and skills of engineering manufacture of processed agricultural products for farmers including women farmers, and be able to improve the micro-enterprise business management capabilities in the field of agro-industries and developing the productive effort of farmers. The method used is the lecture method and the method of integrative theoretical practical experience and practices regarding the management approach practical (production management, financial management marketing management, small business management micro and entrepreneurship. The results of this work show that farmers, especially women farmers in two villages target participant activity is very appreciated and enthusiastic about the implementation of these activities. Participants don't have enough information that comes straight to them about the opportunities that can be gained through the activities of entrepreneurship in the field of agro-industry that sutable with the daily activities in agribusiness sector. Nevertheless, there are still some problems, especially with the time and cost of organizing this event. It is expected that in future community service activities can be done more efficiently thus giving activity effective results, productive and optimal.
\end{abstract}

Keywords: Practical Management, micro -small enterprises, agro-industry, entrepreneurship. 


\begin{abstract}
Abstrak. Kabupaten Subang merupakan salah satu sentra produksi beberapa komoditas unggulan agribisnis di Jawa Barat, namun tingkat pemanfaatan sebagian hasil produksi agribisnis sebagai bahan baku agroindustri melalui kegiatan mandiri wirausaha dari masyarakat petani yang masih kurang menjadi faktor yang melatarbelakangi dilaksanakannya kegiatan pengabdian masyarakat ini. Usaha mikro dan usaha kecil sudah terbukti mampu memberikan kontribusi yang signifikan kepada perekonomian nasional di Indonesia. Berdasarkan hal ini maka menjadi sebuah kepentingan untuk melakukan pelatihan/pembinaan kepada para petani sebagai salah satu pelaku agribisnis dalam upaya peningkatan pengetahuan, keterampilan mengenai manajemen praktis usaha mikro berbasis agroindustri dalam upaya menumbuhkan jiwa beriwrausaha, untuk membantu berkontribusi secara nyata bagi peningkatan pendapatan ekonomi keluarga. Kegiatan ini dilakukan dengan tujuan untuk menumbuhkan jiwa kewirausahaan, pengetahuan manajemen praktis, serta pengetahuan dan keterampilan teknik pembuatan produk olahan hasil pertanian bagi para petani diantaranya wanita tani, serta mampu meningkatkan kemampuan manajemen bisnis usaha mikro di bidang agroindustri dan mengembangkan usaha produktif petani. Metode yang digunakan adalah metode ceramah dan metode integratif teoritis pengalaman praktis dan praktek mengenai pendekatan manajemen praktis (manajemen produksi, manajemen keuangan manajemen pemasaran, manajemen usaha kecil-mikro dan kewirausahaan. Hasil yang diperoleh dari kegiatan ini menunjukkan bahwa petani terutama wanita tani di kedua desa yang menjadi sasaran perserta kegiatan sangat mengapresiasi dan antusias terhadap dilaksanakannya kegiatan ini. Peserta merasa masih belum terlalu banyak informasi yang langsung datang kepada mereka mengenai banyaknya peluang yang dapat diperoleh melalui kegiatan berwirausaha di bidang agroindustri yang disesuaikan dengan kegiatan masyarakat sehari - hari di bidang agribisnis. Namun demikian, masih terdapat beberapa kendala terutama yang dengan waktu dan biaya dalam penyelenggaraan kegiatan ini. Sehingga diharapkan pada masa yang akan datang kegiatan pengabdian kepada masyarakat ini dapat dilakukan dengan lebih efisien sehingga memberikan aktivitas hasil yang efektif, produktif dan optimal.
\end{abstract}

Kata Kunci: Manajemen praktis, usaha mikro - kecil, agroindustri, kewirausahaan.

\title{
1. Pendahuluan
}

Pertanian merupakan salah satu sektor yang memberikan kontribusi terbesar dalam perekonomian di Indonesia. Kontribusi ini tentunya memiliki peran yang sangat penting bagi bangsa Indonesia. Oleh karena itu, pengembangan pertanian selayaknya harus terus diupayakan agar peran pentingnya dalam perekonomian bangsa tetap terjaga. Namun, permasalahan bangsa yang kompleks saat ini berdampak buruk bagi pengembangan sektor pertanian yang berjalan lambat.

Kabupaten Subang sebagai salah satu sentra pertanian di wilayah di Jawa Barat, memiliki beberapa keunggulan komparatif. Salah satunya adalah kondisi tanah yang relatif lebih subur dan cocok untuk beragam komoditi pertanian dan jumlah penduduk yang besar. Hal tersebut berimplikasi pada sistem pertanian yang tampak sangat beragam. 
Di Indonesia, usaha mikro dan usaha kecil telah memberikan kontribusi yang signifikan kepada perekonomian nasional. Sebagai gambaran, pada tahun 2000 tenaga kerja yang diserap industri rumah tangga (salah satu bagian dari usaha mikro sektor perindustrian) dan industri kecil mencapai $65,38 \%$ dari tenaga kerja yang diserap sektor perindustrian nasional. Pada tahun yang sama sumbangan usaha kecil terhadap total PDB mencapai 39,93\% (BPS, 2001). Usaha mikro yang mengembangkan usaha berbasis komoditas lokal saat ini merupakan salah satu komponen utama pengembangan ekonomi lokal, dan berpotensi meningkatkan posisi tawar petani (bargaining position) dalam agribisnis.

Secara garis besarnya kegiatan usaha kecil dan menengah dengan mengambil basis kegiatan pertanian dapat dikelompokkan dalam 2 kegiatan, yaitu: Agribisnis dan Agroindustri. Agribisnis adalah kegiatan usaha yang membudidayakan tanaman, ternak mulai dari saat awal pertumbuhan hingga menghasilkan produk siap konsumsi dan siap olah untuk proses lebih lanjut. Sedangkan agroindustri adalah usaha yang mengolah bahan mentah dari pertanian termasuk di dalamnya tanaman dan ternak sedemikian rupa menghasilkan produk hasil olahan yang beragam jenis dan manfaatnya. Sementara itu kegiatan agroindustri pada dasarnya merupakan kegiatan tindak lanjut dari usaha yang dilakukan dalam agribisnis dimana output dari agribisnis merupakan bahan baku bagi kegiatan agroindustri. Dengan demikian tahapan kegiatannya merupakan kelanjutan dari kegiatan agribisnis, yaitu sebagai berikut:

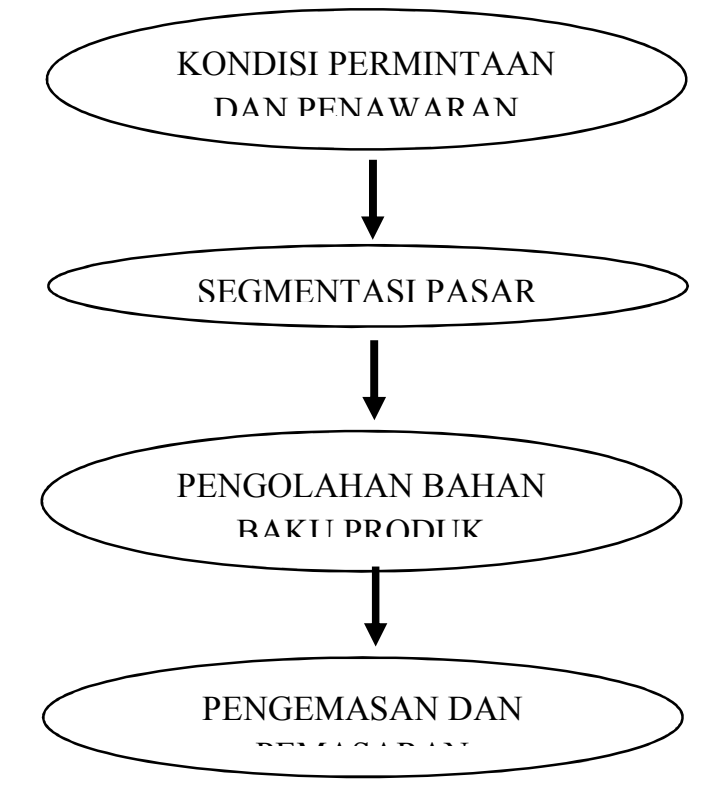

\section{Gambar 1. Tahapan Kegiatan Agroindustri}

Desa Palasari dan Desa Cisaat di Kec. Ciater, Kab. Subang merupakan dua desa sebagian besar warganya bekerja di sektor pertanian. Desa Palasari merupakan desa yang dikelilingi dengan perkebunan teh dan hortikultura membuat sebagian besar mata pencaharian dari warga Desa Palasari ini adalah petani sayuran dan juga pemetik teh. Sedangkan Desa Cisaat yang berlokasi lebih dekat dengan jalan raya Subang - Bandung memiliki keadaan alam yang subur dan nyaris tidak ada lahan gundul menjadikan 
daerah ini bebas dari ancaman tanah longsor, sehingga wilayahnya juga sebagian besar digubakan untuk area pertanian terutama jenis hortikultura. Terdapat banyak jenis komoditas hrotikultura yang diusahakan di wilayah ini, salah satu komoditas unggulannya adalah jenis buah pisang. Di kedua desa ini buah pisang dibudidayakan cukup banyak, namun hampir seluruh hasil panennya hanya dijual dalam bentuk segar (fresh cut) dengan cara tradisional yaitu dari petani ke tengkulak atau Bandar. Sangat sedikit dan jarang sekali hasil buah pisang yang cukup melimpah tersebut diolah kembali dalam bentuk lain yang secara nilai value) mampu memberikan keuntungan yang lebih besar kepada petani melalui kegiatan agroindustri.

Dengan melihat fenomena - fenomena yang diungkapkan tersebut, maka menjadi sebuah kepentingan untuk melakukan pelatihan/pembinaan kepada para petani sebagai salah satu pelaku agribisnis. Pelatihan atau workshop ini dilakukan dalam upaya peningkatan pengetahuan, keterampilan mengenai manajemen praktis usaha mikro berbasis agroindustri dalam upaya menumbuhkan jiwa beriwrausaha, untuk membantu berkontribusi secara nyata bagi peningkatan pendapatan ekonomi keluarga.

Tujuan dilaksanakannya workshop ini diharapkan mampu menumbuhkan jiwa kewirausahaan, pengetahuan manajemen praktis, serta pengetahuan dan keterampilan teknik pembuatan produk olahan hasil pertanian, sehingga mampu meningkatkan kemampuan manajemen bisnis usaha mikro di bidang agroindustri, dan mengembangkan usaha produktif petani.

\section{Metode Pengabdian}

Metode yang akan digunakan dalam program pengabdian masuarakat Integratif ini adalah melalui: a) metode ceramah; b) metode integratif teoritis, pengalaman praktis dan praktek atau praktek demonstrasi (berdasarkan materinya); c) serta tutorial melalui pendekatan manajemen praktis (manajemen produksi, manajemen keuangan manajemen pemasaran, dsb), manajemen usaha kecil-mikro dan kewirausahaan (berdasarkan substansinya). Model kerangka pemecahan masalah dalam kegiatan ini dapat dilihat pada gambar 2. Berdasarkan model kerangka pemecahan masalah pada gambar 2, realisasi yang dilakukan adalah sebagai berikut:

1. Mengetahui manfaat buah pisang

Peserta pelatihan diberikan modul tentang manfaat buah pisang, dijelaskan secara rinci tentang manfaat buah pisang dan fungsi serta penggunaanya. Hasil yang diperoleh masyarakat mulai memahami manfaat, pengetahuan dasar untuk praktik pembuatan olahan dari pisang yang bahan dasarnya dari pisang.

2. Memahami proses dan praktik pembuatan produk olahan dari buah pisang. peserta pelatihan diberikan pedoman proses berupa hand out dan tata cara pembuatan makanan dari buah pisang. Buah pisang banyak tumbuh di hampir semua pekarangan rumah masyarakat terutama di desa karena mempunyai lahan yang cukup sehingga buah pisang bisa didapatkan dari lingkungan sekitar masyarakat maupun bisa di beli di pasar. Sedangkan peralatan yang dibutuhkan untuk membuat olahan pisang bisa di beli di pasar atau dapat diperoleh di tokotoko peralatan rumah tangga. Proses pembuatan makanan/produk olahan pisang 
diperagakan oleh pembicara dan terutama adalah produk berupa brownies pisang.

3. Memahami peluang usaha dan potensi produk dari buah pisang.

Materi pelatihan kewirausahaan menggunakan modul mengenai kewirausahaan diberikan di Desa Palasari dan Desa Cisaat. Modul ini diberikan melalui tutorial dan pelatihan dihadapan para peserta pelatihan di kedua desa dengan langsung bertatap muka, fasilitator memberikan penjelasan dan kemudian dilaksanakan diskusi dan tanya jawab. Selanjutnya diberikan penjelasan mengenai prospek yang menjanjikan dan berkelanjutan dari pembuatan produk dari buah pisang, sehingga bisa menjadi usaha yang bisa di lakukan bersama-sama dan berkelanjutan.

4. Menumbukan Jiwa Kewirausahaan Masyarakat

Pada saat workshop peserta diajak berdiskusi dan berpartisipasi aktif dalam membuat produk dari buah pisang. Selain itu penggunaan kata dan pola diskusi yang mampu diterima oleh masyarakat desa memberikan mereka semangat dan antusiasme dalam mengikuti kegiatan samapai akhir. Selain itu mereka secara tidak langsung bisa menyerap semua kegiatan pada proses pembuatan produk berbahan dasar buah pisang yang nantinya bisa mereka aplikasikan di rumah tangga dengan harapan bisa juga dijual dengan memperhatikan kemasan dan pasar sasaran (misal pada saat acara hajatan, sunatan, pengajian, arisan dll). Dalam kaitan dengan memperluas pangsa pasar untuk menumbuhkan keinnginna mennghasilkan produk yang tersertifikasi, pemateri memberikan arahan tentang pembuatan produk yang mempunyai ijin P-IRT (pangan industry rumah tangga).

5. Terciptanya pola usaha produk olahan berdasarkan manajemen usaha yang baik Pertemuan dan diskusi antara masyarakat Desa Palasari dan Desa Cisaat Kabupaten Subang dengan narasumber tentang bagaimana menngelola usaha kecil yangbaik dengan pencatatan baik tentang pemasukan maupun pengeluaran sehingga laba atau keuntungan usaha yang dihasilkan jelas. Bagaimana mengatur tentang pengelolaan usaha yang terpisah dari pengeluaran rumah tangga. Penjelasan ini berguna agar masyarakat peserta menyadari dan mampu merencanakan, mengatur, mengorganisasikan dan mengimplementasikan bagaimana pengelolaan usaha dengan prinsip manajemen yang baik sehingga dapat meningkatkan pendapatan masyarakat desa pada umumnya. 


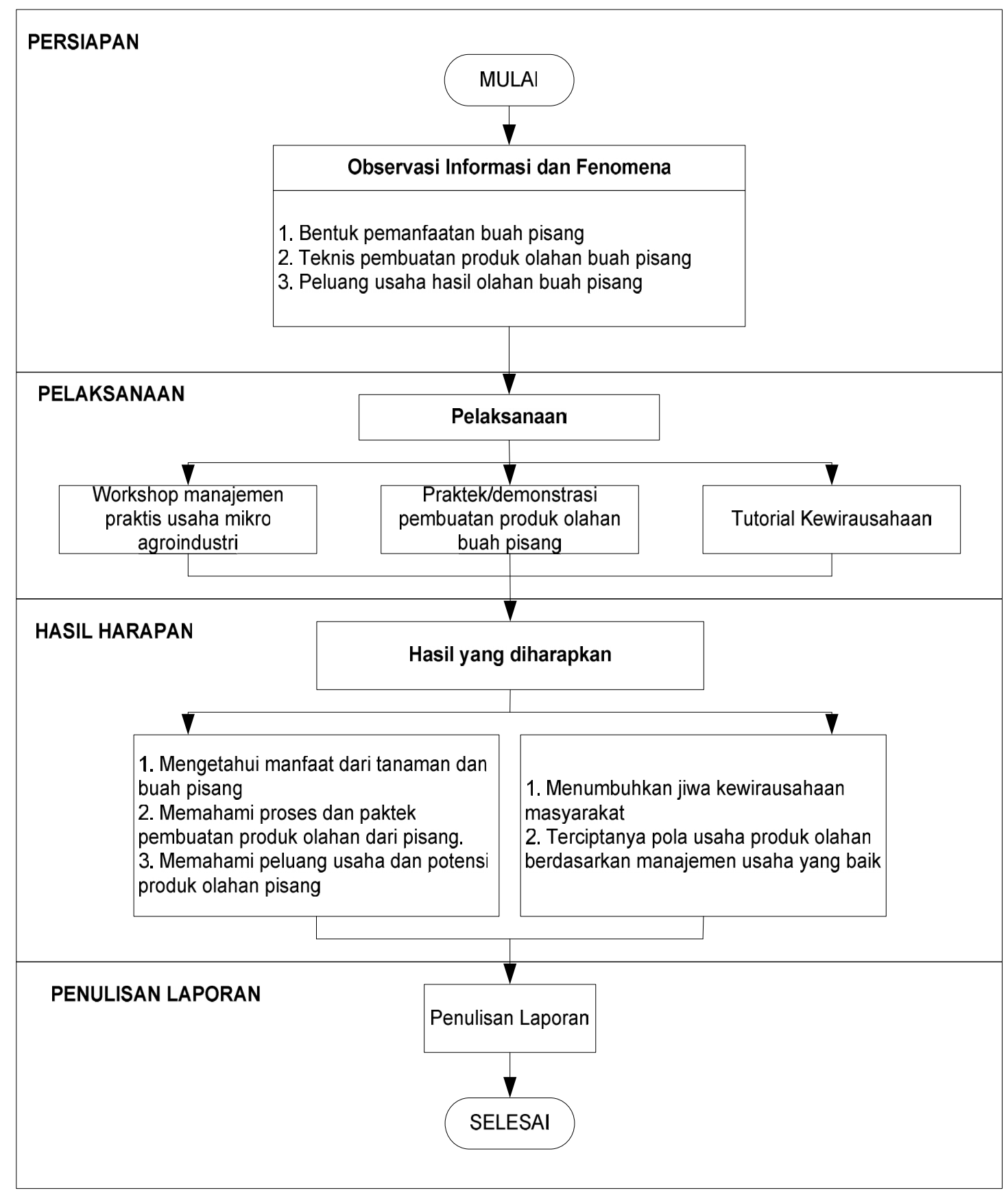

Gambar 2. Kerangka Penyelesaian Masalah

\section{Hasil dan Pembahasan}

Usaha mikro tergolong jenis usaha marginal, ditandai dengan penggunaan teknologi yang relatif sederhana, tingkat modal dan akses terhadap kredit yang rendah, serta cenderung berorientasi pada pasar lokal. Namun demikian sejumlah kajian di beberapa Negara menunjukkan bahwa usaha mikro berperanan cukup besar bagi pertumbuhan ekonomi, menyerap tenaga kerja melalui penciptaan lapangan pekerjaan, menyediakan barang dan jasa dengan harga murah, serta mengatasi masalah 
kemiskinan. Disamping itu, usaha mikro yang mengembangkan usaha berbasis komoditas lokal juga merupakan salah satu komponen utama pengembangan ekonomi lokal, dan berpotensi meningkatkan posisi tawar petani (bargaining position) dalam agribisnis.

Berdasarkan positioning usaha mikro atau kecil yang berbasis agribsinis teruatama di Negara - Negara berkembang seperti Indonesia yang terbukti mampu bertahan meskipun dalam kondisi ekonomi yang kurang stabil. Sehingga perlu adanya upaya - upaya yang turut dilakukan oleh lembaga pendidikan diantaranya perguruan tinggi untuk turut membantu mensosialisasikan dan menumbuhan jiwa berwirausaha para pelaku pertanian diantaranya petani. Sosialisasi dan pembinaan dapat dimulai dari skala wirausaha dalam skala rumah tangga atau mikro disertai dengan pengenalan usaha berbasis agroindustri. Kegiatan workshop ini dikemas dalam bentuk pembelajaran dengan materi pembahasan difokuskan pada pedoman manajemen praktis dan usaha mikro praktis, yang diharapkan mampu memberikan keragaman yang berbeda pada program - program pemberdayaan masyarakat di pedesaan, khususnya pemberdayaan perempuan di pedesaan. Melalui penumbuhan jiwa berwirausaha dan pengetahuan tentang manajemen praktis sebagai aspek yang dianggap sebagai gate keeper dalam sebuah usaha atau bisnis dapat dijadikan sebagai sarana efektif untuk kegiatan belejar, berkreasi dan berkretifitas, serta pemupukan minat jiwa berwirausaha teruatama bagi para petani.

Dengan dilakukannya workshop dan pembinaan ini diharapkan para petani mengetahui peluang dan perkembangan yang sedang dan akan terjadi melalui berwirausaha dalam bidang agrindustri meskipun masih dalam skala usaha mikro yang dapat berpengaruh langsung pada ekonomi dan kesejahteraan keluarga. Para petani di desa selanjutnya bila akan melakukan wirausaha mikro diharapkan dapat berkomuniasi dan bekerja sama dengan pihak-pihak lain terkait yang mampu memberikan masukan, antisipasi, dan solusi permasalaan yang mungkin akan terjadi. Langkah - langkah strategis yang sifatnya praktis yang telah disampaikan sebelumnya, diharapkan mampu membentuk kemandirian petani yang pada akhirnya mampu menjadi salah satu upaya pencapaian peningkatan kesejahteraan masyarakat pedesaan sebagai bagian dari pembangunan pertanian dan sumber daya manusia.

Hasil yang dicapai pasca kegiatan pelatihan wirausaha pengolahan buah pisang ini adalah sebagai berikut:

1. Bagi ibu rumah tangga petani dan non petani

a. Tingkat Partisipasi

Berdasarkan hasil kajian (Participatory Rural Appraisal) PRA berupa keadaan sumberdaya dan pemetaan sosial masyarakat di Desa Palasari dan Desa Cisaat, maka lokasi yang tepat dan cocok sebagai desa sasaran pelatihan pembuatan aneka makanan dari buah pisang adalah kedua desa tersebut. Dasar pertimbangannya adalah sebagai berikut:

1) Sebagian besar masyarakat desa Palasari dan Cisaat bermatapencaharian sebagai petani, buruh tani dan penggarap lahan tani dan rata-rata pohon pisang tumbuh di kedua desa tersebut. 
2) Kegiatan kelompok ibu-ibu pengajian dan ibu-ibu rumah tangga cukup bagus untuk bisa dijadikan kelompok sasaran dengan bantuan koordinasi dengan aparat desa setempat.

3) Keinginan muncul dari kepala desa dan masyarakat sendiri ketika ditawarkan mengenai program pelatihan pembuatan aneka makanan dari pisang. Antusiasme ibu-ibu rumah tangga sebagai kelompok saasaran cukup tinggi dan mereka sangat ingin mengetahui informasi lebih banyak program pelatihan ini.

b. Pengetahuan dan keterampilan Teknis

Hasil yang dicapai adalah terjadinya peningkatan pengetahuan teknis pembuatan aneka makanan dari pisang terutama brownis pisang. Masyarakat desa yang tadinya hanya memanfaatkan buah pisanng untuk konsumsi langsung menjadi bila lebih memberdayagunakan buah pisang ke dalam bentuk yang lain dan mempunyai nilai ekonomis jika diusahakan. Teknis pembuatan sederhana diberikan kepada mereka dalam bentuk modul dan gambar proses pengolahan pembuatan aneka makanan olahan dari pisang yang disajikan secara informatif dan sederhana. Pengetahuan teknis yang diberikan antara lain:

1. Pengetahuan mengenai pemilihan bahan baku yang tersedia di lokasi kajian seperti kriteria dan syarat buah pisang.

2. Pengetahuan mengenai komposisi dan cara pencampuran bahan bahan yang diperlukan

3. Pengetahuan mengenai proses produksi mulai dari a) pemilihan bahan; b) pencampuran bahan; c) teknis pembuatan

Proses-proses tersebut diikuti oleh ibu-ibu rumah tangga dan juga masyarakat desa dengan pemaparan oleh narasumber kemudian dilanjutkan dengan praktek pembuatan aneka makanan dari buah pepaya. Hasil yang didapatkan bahwa masyarakat desa khususnya ibu-ibu rumah tangga bisa memahami teknis pembuatan makanan dari buah pisang mulai dari awal sampai akhir.

c. Pengetahuan manajemen

Peserta pelatihan mengerti dan memahami konsep dan penerapan kewirausahaan, memahami jenis-jenis usaha yang sesuai dengan karakter dan ketersediaan sumber daya. Serta mampu mengetahui apa yang dimaksud dengan kemandirian, baik kemandirian financial, kemandirian usaha dan keberlanjutan usaha.

d. Keterampilan manajemen kewirausahaan

Perlu pelatihan lanjutan untuk mengembangkan usaha dengan pembuatan business plan dan analisis usaha pembuatan anekan makanan dari buah pisang secara berkesinambungan

e. Analisis Sumber dan Ketersediaan Bahan

Bahan baku yang tersedia di lokasi kegiatan baik berupa sumber daya manusia maupun bahan baku buah pisang sangat melimpah karena pohon pisang bisa tumbuh di mana saja dan tidak membutuhkan waktu dan perawatan yang sulit sehingga bisa di usahakan.

2. Fasilitator, Pemateri (Pakar dan Praktisi) dan Pendamping

a. Metode Pembelajaran 
Metode pembelajaran dilaksanakan secara partisipatif mulai dari awal sampai akhir kegiatan. Keadaan ini dilaksanakan berdasarkan kebutuhan masyarakat desa sendiri. Metode pembelajaran untuk desa Palasari dilakukan di aula kantor desa Palasari sedangkan untuk desa Cisaaat dilakukan di (Balai Desa) Bale Sawala Anggawana yang terletak sekitar $100 \mathrm{~m}$ dari balai desa, dengan pertimbangan terdapat di tengah pemukiman masyarakat. Secara rinci metode bertahap tersebut adalah pemberian materi mengenai manfaat dan fungsi tanaman dan buah pisang kemudian dilanjutkan dengan praktek pembuatan makanan dari buah pisang

b. Metode Fasilitasi

Metode fasilitasi disini sudah diterapkan dan tentu saja melibatkan masyarakat, dengan mempertemukan antara narasumber pembuatan makanan dari buah pisang dengan masyarakat di Desa Palasari dan CIsaat, agar tercipta kerjasama usaha yang berkelanjutan baik kerjasama produksi maupun pemasaran. Kerjasama ini ditunjukkan pula dengan antusiasme dan semangat masyarakat untuk mendapatkan pengetahuan baru yang berpotensi meningkatkan pendapatan mereka.

c. Metode Pendampingan

Pendampingan ini diawali dari sosialisasi pelaksanaan dan penjelasan program kegiatan kepada masyarakat desa khususnya kelompok pengajian dan ibu-ibu rumah tangga sampai dengan praktek pembuatan makanan dari buah Pisanng.

d. Materi Pembelajaran

Materi pembelajaran diberikan sesuai dengan kebutuhan dan terintegrasi, artinya materi yang diberikan berupa modul tentang teknis pembuatan makanan dari buah pisang sampai dengan modul kewirausahaan yang disajikan dalam bahasa yang mudah dipahami dan ringkas padat. Sehingga integrasi antar produksi sampai dengan metode kerjasama usaha dan pemasaran dapat diberikan dan alur pembelajaran dapat diikuti dengan baik oleh peserta pelatihan.
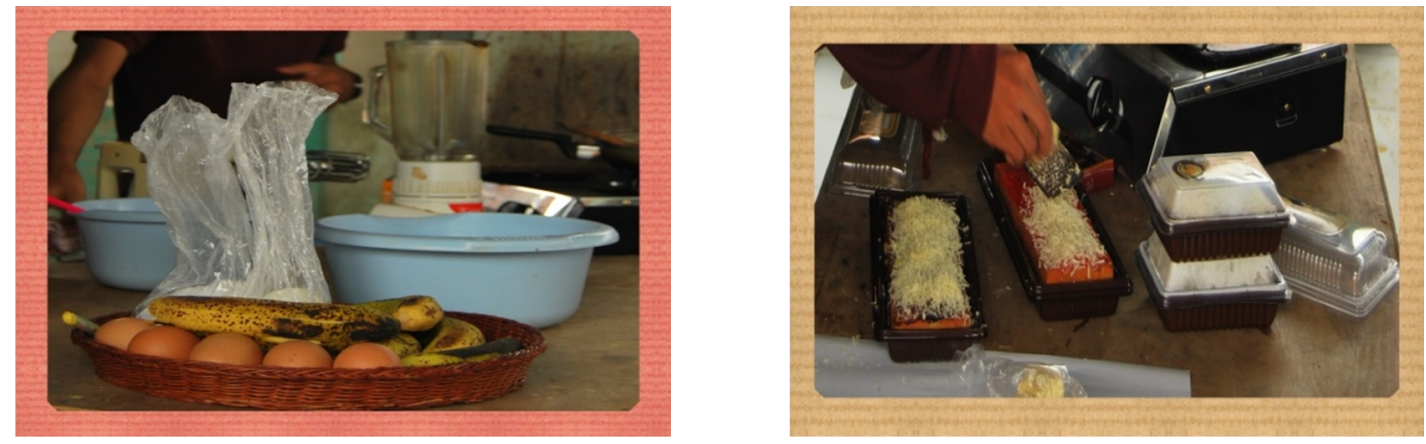


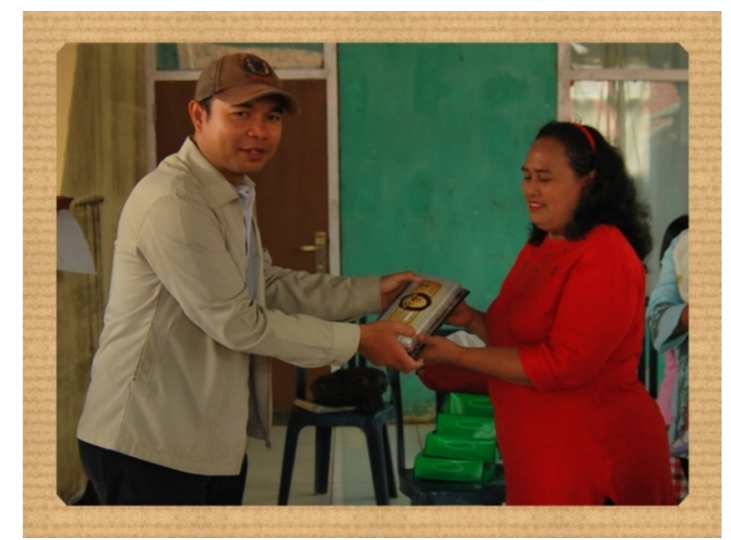

Gambar 3. Pelatihan Berwirausaha

Keberhasilan pelatihan dan pembinaan bagi para petani sebagai peserta ini akan diukur berdasarkan tingkat partispasi para petani dalam ikut terlibat dalam setiap rangkaian kegiatan yang ada di dalam workshop, baik kegiatan yang dilaksnakan di kelas maupun pada saat praktek di lapangan,serta ukuran adanya perubahan perilaku para peserta (pengetahuan, persepsi, motivasi, sikap dan keterampilan) dalam menggunakan komoditas hasil usaha taninya untuk diusahakan dalam aktivitas kewirausahaan sehingga mampu memberikan nilai ekonomis yang lebih tinggi, yang dilakukan berdasarkan pengetahuan dan kemampuan manajemen bisnis yang praktis dalam menjalankan sebuah usaha/wirausaha, berdasarkan produktivitas yang diperoleh dari praktek hasil pelatihan serta menumbuhkan keinginan dan motivasi yang kuat untuk mulai melakukan kegiatan beriwrausaha dikemudian hari.

Indikator keberhasilan kegiatan bagi fasilitator atau pendamping masyarakat desa adalah dengan melakukan penilaian berdasarkan efektivitas dalam memfasilitasi dan mendampingi para petani selama rangkaian kegiatan. Sedangkan bagi para narasumber atau praktisi yang memberikan materi bagi para petani akan dinilai berdasarkan efektivitas metode pembelajaran yang digunakan serta materi yang diberikan untuk diimpllementasikan atau diaplikasikan kepada para petani. Penilaian yang dilakukan meliputi faktor kemudahan pemehaman materi, kemudahan penerapan materi dikemudian hari melalui kesesuaian materi yang diberikan dengan yang dibutuhkan oleh petani sebagai peserta kegiatan.

Tabel 1.

Indikator Kegiatan dan Perubahan-Perubahan Pasca Kegiatan Manajemen

Praktis Usaha Mikro Berbasis Komoditas Lokal Agro Sebagai Upaya Menumbuhkan Jiwa Kewirausahaan Petani Sebagai Pelaku Agribisnis di Desa Palasari dan Cisaat Kec. Ciater, Kab. Subang

\begin{tabular}{|c|c|c|c|}
\hline No. & \multicolumn{1}{|c|}{ Indikator } & $\begin{array}{c}\text { Base Line } \\
\text { (Sebelum Kegiatan) }\end{array}$ & $\begin{array}{c}\text { Pencapaian } \\
\text { (Setelah Kegiatan) }\end{array}$ \\
\hline 1. & Bagi Para Petani & & \\
\hline
\end{tabular}




\begin{tabular}{|c|c|c|c|}
\hline No. & Indikator & $\begin{array}{c}\text { Base Line } \\
\text { (Sebelum Kegiatan) }\end{array}$ & $\begin{array}{c}\text { Pencapaian } \\
\text { (Setelah Kegiatan) }\end{array}$ \\
\hline & $\begin{array}{l}\text { - Tingkat Partisipasi Para } \\
\text { Petani dalam Kegiatan } \\
\text { (Kelas dan } \\
\text { Praktek/Lapangan) }\end{array}$ & $\begin{array}{l}\text { Partisipasi ibu rumah } \\
\text { tangga Petani dalam } \\
\text { Pelatihan (Terutama } \\
\text { yang Berkaitan dengan } \\
\text { ketertarikan dalam } \\
\text { menimba pengetahuan } \\
\text { dan wawasan baru } \\
\text { mengenai agroindustri) } \\
\text { Masih Lemah }\end{array}$ & $\begin{array}{l}\text { - Terjadinya Peningkatan } \\
\text { Partisipasi Para petani } \\
\text { dalam Kegiatan di Kelas } \\
\text { maupun di Lapangan }\end{array}$ \\
\hline & $\begin{array}{l}\text { - Pengetahuan Teknis } \\
\text { tentang pentingnya arti } \\
\text { manajemen praktis } \\
\text { usaha. }\end{array}$ & $\begin{array}{l}\text { - Pengetahuan Teknis } \\
\text { tentang arti pentingnya } \\
\text { manajemen praktis } \\
\text { usaha masih rendah }\end{array}$ & $\begin{array}{l}\text { - Terjadinya Peningkatan } \\
\text { Pengetahuan Teknis } \\
\text { mengenai manajemen } \\
\text { praktis usaha }\end{array}$ \\
\hline & $\begin{array}{l}\text { - Pengetahuan Teknis } \\
\text { tentang pentingnya arti } \\
\text { usaha mikro berbasis } \\
\text { agroindustri. }\end{array}$ & $\begin{array}{l}\text { - Pengetahuan Teknis } \\
\text { tentang arti pentingnya } \\
\text { usaha mikro berbasis } \\
\text { agroindustri masih } \\
\text { rendah }\end{array}$ & $\begin{array}{l}\text { - Terjadinya Peningkatan } \\
\text { Pengetahuan Teknis } \\
\text { mengenai usaha mikro } \\
\text { berbasis agroindustri }\end{array}$ \\
\hline & $\begin{array}{l}\text { - Pengetahuan } \\
\text { Memahami } \\
\text { (lingkungan internal) } \\
\text { kekuatan (potensi) dan } \\
\text { kelemahan petani bila } \\
\text { melakukan usaha mikro } \\
\text { berbasis agrindustri }\end{array}$ & $\begin{array}{l}\text { Pengetahuan } \\
\text { Memahami } \\
\text { (lingkungan internal) } \\
\text { kekuatan (potensi) dan } \\
\text { kelemahan petani bila } \\
\text { melakukan usaha } \\
\text { mikro berbasis } \\
\text { agroindustri masih } \\
\text { rendah } \\
\end{array}$ & $\begin{array}{l}\text { - Terjadinya Peningkatan } \\
\text { pemahaman } \\
\text { (lingkungan internal) } \\
\text { kekuatan (potensi) dan } \\
\text { kelemahan petani bila } \\
\text { melakukan usaha mikro } \\
\text { berbasis agroindustri }\end{array}$ \\
\hline & $\begin{array}{l}\text { Keterampilan petani } \\
\text { dalam menganalisis } \\
\text { dan memperhitungkan } \\
\text { (lingkungan eksternal) } \\
\text { peluang dan tantangan } \\
\text { yang dihadapi, pada } \\
\text { saat ini dan masa } \\
\text { mendatang terkait } \\
\text { manajemen praktis } \\
\text { usaha mikro berbasis } \\
\text { agroindustri }\end{array}$ & $\begin{array}{l}\text { Belum Memiliki } \\
\text { Keterampilan dalam } \\
\text { Memperhitungkan } \\
\text { peluang dan tantangan } \\
\text { yang dihadapi, pada } \\
\text { saat ini dan masa } \\
\text { mendatang terkait } \\
\text { manajemen praktis } \\
\text { usaha mikro berbasis } \\
\text { agroindustri }\end{array}$ & $\begin{array}{l}\text { - Terjadinya Peningkatan } \\
\text { Keterampilan dalam } \\
\text { Memperhitungkan } \\
\text { peluang dan tantangan } \\
\text { yang dihadapi, pada saat } \\
\text { ini dan masa mendatang } \\
\text { terkait manajemen } \\
\text { praktis usaha mikro } \\
\text { berbasis agroindustri }\end{array}$ \\
\hline & $\begin{array}{l}\text { Keterampilan petani } \\
\text { dalam mempraktekan } \\
\text { salah satu contoh } \\
\text { produk olahan } \\
\text { berbahan baku } \\
\text { komoditas lokal }\end{array}$ & $\begin{array}{l}\text { Petani belum mampu } \\
\text { mempraktekan salah } \\
\text { satu contoh produk } \\
\text { olahan berbahan baku } \\
\text { komoditas lokal }\end{array}$ & $\begin{array}{l}\text { Dihasilkan sebuah } \\
\text { contoh pilihan produk } \\
\text { olahan agroindustri. }\end{array}$ \\
\hline & $\begin{array}{l}\text { - Keterampilan petani } \\
\text { dalam pemilihan }\end{array}$ & $\begin{array}{l}\text { - Petani belum mampu } \\
\text { mengembangkan }\end{array}$ & $\begin{array}{l}\text { - Dihasilkan sebuah } \\
\text { stategi terbaik bagi }\end{array}$ \\
\hline
\end{tabular}




\begin{tabular}{|c|c|c|c|}
\hline No. & Indikator & $\begin{array}{c}\text { Base Line } \\
\text { (Sebelum Kegiatan) }\end{array}$ & $\begin{array}{c}\text { Pencapaian } \\
\text { (Setelah Kegiatan) }\end{array}$ \\
\hline & $\begin{array}{l}\text { alternatif strategi } \\
\text { manajemen praktis } \\
\text { yang ada untuk } \\
\text { mengatasi masalah } \\
\text { yang dihadapi bila } \\
\text { melakukan usaha mikro } \\
\text { agroindustri }\end{array}$ & $\begin{array}{l}\text { alternatif strategi untuk } \\
\text { mengatasi } \\
\text { permasalahan yang ada } \\
\text { bila melakukan usaha } \\
\text { mikro agroindustri }\end{array}$ & $\begin{array}{l}\text { pemecahan } \\
\text { permasalahan yang } \\
\text { dihadapi oleh petani bila } \\
\text { melakukan usaha mikro } \\
\text { agroindustri }\end{array}$ \\
\hline 2. & \multicolumn{3}{|c|}{ - Bagi Fasilitator, Pemateri (Pakar dan Praktisi) dan Pendamping } \\
\hline & - Metode Pembelajaran & $\begin{array}{l}\text { Penyuluhan dengan } \\
\text { hanya satu arah }\end{array}$ & $\begin{array}{l}\text { Partisipatif, Belajar } \\
\text { Teori, Pengalaman di } \\
\text { tempat Para Petani dan } \\
\text { penyuluhan dua arah }\end{array}$ \\
\hline & - Metode Fasilitasi & - Belum diterapkan & $\begin{array}{l}\text { Diterapkan dan } \\
\text { Melibatkan Masyarakat } \\
\text { terrutama petani sebagai } \\
\text { peserta }\end{array}$ \\
\hline \multirow[t]{4}{*}{ No. } & Indikator & $\begin{array}{c}\text { Base Line } \\
\text { (Sebelum Kegiatan) }\end{array}$ & $\begin{array}{c}\text { Pencapaian } \\
\text { (Setelah Kegiatan) }\end{array}$ \\
\hline & - Metode Pendampingan & $\begin{array}{l}\text { Masih kurangnya focus } \\
\text { kepada pengembangan } \\
\text { dan pembinaan bagi } \\
\text { petani dalam upaya } \\
\text { penumbuhan jiwa } \\
\text { wirasuaha di bidang } \\
\text { agroindustri }\end{array}$ & $\begin{array}{l}\text { - Diterapkan, baik oleh } \\
\text { fasilitator dan pemateri }\end{array}$ \\
\hline & - Materi Pembelajaran & $\begin{array}{l}\text { Masih kurangnya } \\
\text { upaya memandirikan } \\
\text { dan memberdayakan } \\
\text { petani }\end{array}$ & $\begin{array}{l}\text { - Sesuai dengan } \\
\text { kebutuhan dan } \\
\text { teritegrasi }\end{array}$ \\
\hline & $\begin{array}{l}\text { - Alat Bantu } \\
\text { Pembelajaran }\end{array}$ & $\begin{array}{l}\text { Hanya melalui lisan } \\
\text { dan kegiatan kelompok }\end{array}$ & $\begin{array}{l}\text { - Terintegrasi, Langsung, } \\
\text { Audio Visual dan } \\
\text { Praktik }\end{array}$ \\
\hline
\end{tabular}

\section{Kesimpulan dan Saran}

\subsection{Kesimpulan}

Kegiatan workshop tentang manajemen praktis pengelolaan dan pencatatan dalam kegiatan usaha sangatlah penting karena setelah di tinjau dari kegiatan yang dilakukan manajemen pengeolaan usaha seringkali diabaikan sehingga seringkali salah salam mengelolla keuangan usaha dan juga salah dalam memprediksi kegiatan usaha sehingga usaha yang dijalankan oleh rumah tangga petani maupun non rumah tangga petani baik di Desa palasari maupun di Desa Cisaat kurang berkembang dan kurang berdaya.

Pelatihan pembuatan olahan brownis dari pisang ternyata sangat diminati oleh sebagian peserta dan mereka antusisa sekali namun keluhan dari peserta berupa 
kurangnya kegiatan sejenis yang dilakukan. Kegiatan pelatihan tersebut menambah informasi baru bagi masyarakat desa terutama ibu-ibu rumah tangga.

Sebagian besar masyarakat desa kurang mengenal kegiatan wirausaha yang lebih dikenal adalah kegiatan jual beli. Sehingga teknis penjelasan serta teknik memotivasi agar menumbuhkan minat masayarakat dalam berwirausaha dilakukan secara sederhana. Dari kegiatan yang dilakukan, minat masayarakat untuk berwirausaha cukup besar namun mereka rata-rata masih terkendala pada kegiatan pemasaran hasil usahanya. Namun dari panatauan dan kegiatan yang dilakukan terlihat nyata sebagian besar mereka sudah melakukan kegiatan wirausaha tapi hanya sebatas kegiatan usaha warunng dan pembuatan kue-kue tradisional yang secara sederhana sehingga daya tahan dan kemasannya kuranng diperhatikan.

\subsection{Saran}

Sedangkan saran yang dapat diberikan adalah perlunya keterlibatan pemerintah kecamatan dan kabupaten dalam membatu pembinaan dan pelaksanaan kegiatan pelatihan pengolahan aneka produk dari hasil pertanian dan teknik pengemasan. Selain itu perlu dilakukan bantuan kegiatan pemasaran produk atau membuka jejaring pemasaran sehingga kegaiatan wirausaha dengan mengembangkan komoditas lokal yang ada di desa bisa berjalan dengan baik.

\section{Penghargaan}

Kami menyampaikan terima kasih kepada Lembaga Penelitian dan Pengabdian Kepada Masyarakat Universitas Padjadjaran yang telah memberikan dukungan dan kesempatan untuk melaksanakan kegiatan pengabdian kepada masyarakat ini. Ucapan terima kasih juga kami ucapakan kepada semua pihak yang juga turut membantu dalam pencarian dan pengumpulan data yang sangat membantu pada penyelesaian kegiatan pengabdian kepada masyarakat ini dari awal sampai akhir penyelesaian kegiatan.

\section{Daftar Pustaka}

Banana.com. (2002). Medical Uses of Banana. http://www.banana.com/medicinal.html. BPS. (2002). Pertumbuhan Ekonomi Indonesia 2001. http://www.bps.go.id/brs_file/pdb 18peb02.pdf?

BPPT. (1998). Pisang: Budidaya, Pengolahan, dan Prospek Pasar. www.bppt.go.id

Djaenuddin, D., (1996). Evaluasi Sumberdaya Lahan Untuk Menunjang Penataan Ruang

Provinsi Jawa Barat, Bogor: PPTA.

Kasryno, F., (1984). Kerangka Analisa Ekonomi Masalah Pedesaan Prospek

Pembangunan Ekonomi Pedesaan Indonesia. Jakarta: Yayasan Obor Indonesia. Lutfi, I Nasution. (1997). Pengaturan Penguasaan Penggunaan Tanah dalam Upaya Pengendalian Fungsi Lahan Tanah Pertanian Sawah Beririgasi dan Mempertahankan Swasembada Beras. Proceeding Seminar Nasional Studi Kebijakan Tata Ruang dan Pertanahan. Yogyakarta. 
326 | Pandi Pardian, et al.

Suyanti dan S. Supriadi. (2008). Pisang, Budidaya, Pengolahan, dan Prospek Pasar. Jakarta:

Penebar Swadaya.

Porter, M. E. (1985). Competitive Strategy. New York: Free Press

Wikipedia. http://id.wikipedia.org/wiki/Pisang 